\title{
Financing Diversification and Profitability of Islamic Banking in Indonesia
}

\author{
Iin Emy Prastiwi ${ }^{1)}$, Anik ${ }^{2)}$ \\ ${ }^{1,2}$ Sharia Economic faculty, Institute of Business Technology AAS Indonesia \\ *Email correspondence: iinemyprastiwi24@gmail.com
}

\begin{abstract}
This study aims to determine the effect of Islamic bank financing diversification based on economic sectors and based on the type of use on profitability. This study uses financing data for Islamic Banks and Islamic Business Units in 2014-2018. The data in this study are the times series data. Data analyzed by used multiple linear regression analyses. This research provides that results that the HHI of diversification of Islamic bank financing based on the economic sector is positively related to increasing the profitability of Islamic banks. It means diversification of financing based on high economic sectors, has an impact on reducing the profitability of Islamic banks in Indonesia. While the HHI of diversification of financing by type of use give a significant influence in increasing the profitability of Islamic banks in a negative direction. If Islamic banking only focuses on channeling financing to the consumption sector, it can have an impact on decreasing profitability. So that Islamic banking needs to equalize the distribution of consumption to the working capital and investment sectors. The results of this study are interesting because it can be used as a reference for Islamic banking in determining the policy of diversification of financing to obtain high profitability with low risk.
\end{abstract}

Keywords: diversification, profitability, Islamic banks

Citation Suggestions: Prastiwi, I. E., \& Anik. (2021). Financing Diversification and Profitability of Islamic Banking in Indonesia. Jurnal Akuntansi dan Pajak, 21 (2), 412-423. doi:http://dx.doi.org/10.29040/jap.v21i2.1817

DOI: http://dx.doi.org/10.29040/jap.v21i2.1817

\section{INTRODUCTION}

Credit activities (financing) are very important in the economy, especially for countries with a financial system based on a bank (bank base). The best financing method is from managers to use debt (equity) to maximize banking performance (Daud et al., 2016). As a result, the success and failure of banks in managing credit will affect economic activity and development (Christianti, 2011).

Funding is the main activity of banking. Funding is carried out using third party funds, namely funds obtained from the public in the form of savings, time deposits, and current accounts. The higher the distribution of funding provided, the higher the profitability of banks. This is the following research (Marwa, 2013) which concluded that the distribution of funding has a positive effect on profitability.

Profitability is the basis of the relationship between services produced by a bank and the quality of operational efficiency, the more efficient the operations of a bank, the quality of care will increase, and this can increase profitability. Profitability is a more important issue than just profit because large profits alone are not a measure that the company is working efficiently. Profitability ratios are used to measure the effectiveness of management aimed at the size of the level of profits obtained about to with concerning the allocation of funds and investment.

Weygandt et.al (2009), concluded that the profitability ratio is the ratio used to measure the effectiveness of overall company management as indicated by the number of profits earned by the company, in this case, is an Islamic reproduction. Kuncoro, (2002) states that ROA shows management's ability to manage available assets to get net income, while Siamat, (2005) suggests that ROA is a ratio that provides information on how efficient a company is in conducting its business activities because this ratio indicates how much profit can be obtained on average against each rupiah of its assets. In this study, the ratio used to measure the 
performance of a company is Return on Assets (ROA).

According to Moudud-Ul-Huq et al (2018), the best proxy for measuring bank performance is the ROA ratio. Measurement of the company's financial performance with ROA has the advantage that ROA is a comprehensive measurement that entirely affects the financial statements as reflected in this ratio. Another advantage gained from performance measurement with ROA is that ROA is a denominator that can be applied to every organizational unit responsible for profitability and business units (Munawir, 2002).

Financial ratios are said to be useful if they can be used to assist in decision making. If the relationship of financial ratios with earnings growth has a significant effect, it can be said that financial ratios are beneficial, if on the contrary it is said to be not useful (Umam, 2013).

Because of profitability is so important, suitability in allocating bank funds is a major factor in bank sustainability. The purpose of bank fund allocation is to maximize profitability and minimize risk and maintain public confidence in a safe liquidity position. Errors in the allocation of funds affect the level of profitability, the greater the impact on the soundness of a bank. Good bank health can increase the growth of banking assets. The following graph is the growth of Islamic bank assets in 2012 to 2018 .

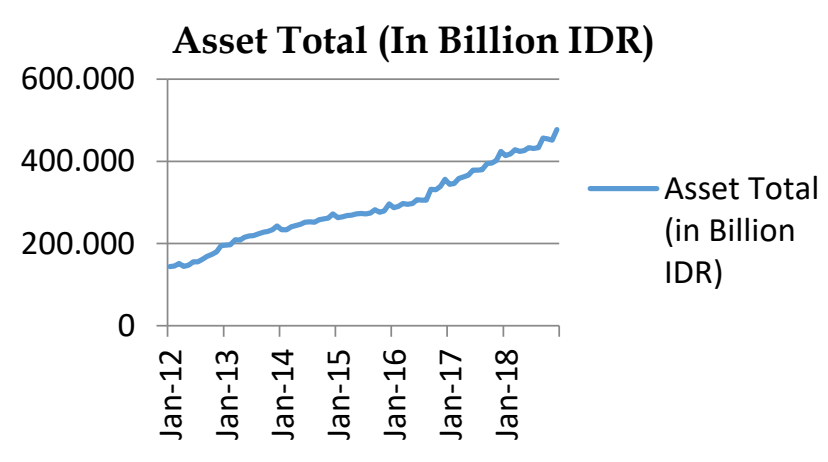

Graph 1. Growth of Islamic Bank Asset 2012-2018

Data source: Islamic banking statistics (processed, 2019)

From the graph above it can be seen that the total assets of Islamic banks have increased from 20122018. The increase in assets indicates that public confidence in Islamic banks is increasing. But the increase in Islamic bank assets is not necessarily in line with the increase in profitability of Islamic banks. Various strategies are carried out by banks to improve profitability, one of those strategies is diversification. In research (Inder Singh, 2014) states that diversification affects assets. The following graph is the profitability of Islamic banks from 2013 until 2018.

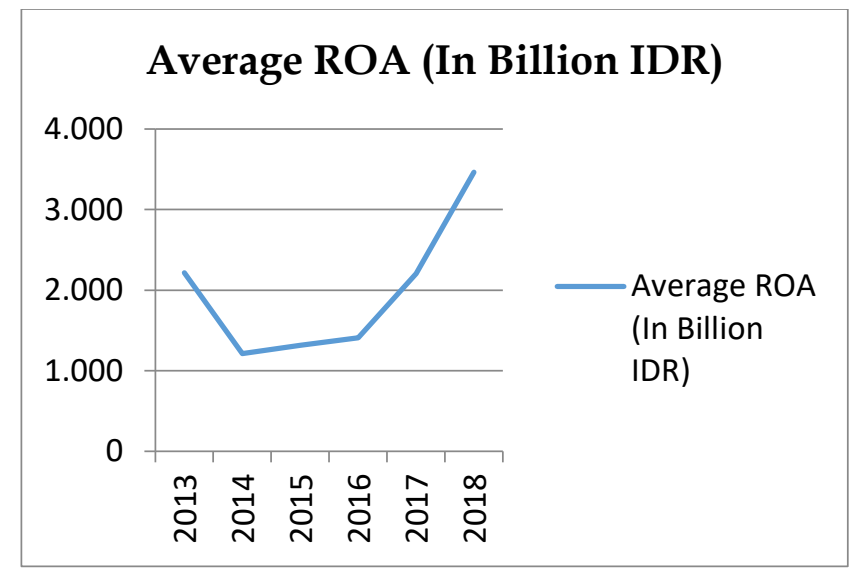

Graph 2. ROA Development of Islamic Banks in 2013-2018

Data source: Islamic banking statistics (processed, 2019)

Unlike the Islamic bank assets which increased from 2012-2018, the profitability of Islamic banks fluctuated up and down in the achievement of profits, as happened in graph 2 above. The profitability of Islamic banks decreased in 2014. The condition did not last long because in 2015 until 2018 there was an increase again. Even the significant increase in 20172018. From the fluctuation of the profitability level, whether the diversification of financing is one of the factors that influence it, this is an interesting background for further research.

Diversification is one of the main topics of financial literacy. This strategy is also important for banks as financial institutions (Turkmen \& Yigit, 2012). Diversification is a form of business expansion geographically or by-products. Satoto (2009) in Chandini Dewi et al., (2017) states that minimizing risk can also be done by diversifying the business. The way to do business diversification is to expand markets that develop new products to suit the market so that they can have an advantage in competing.

Diversification is one of the important strategies for banks as financial institutions. Banks can diversify financing to improve performance and reduce financing risks. Diversification is a strategy that focuses on actions to gain a competitive advantage by selecting and managing different business groups in several industries and markets (David, 2008). Most companies including banks use diversification strategies to enhance strategic competitiveness. When the diversification strategy increases strategic competitiveness, the company's performance will increase. Another reason for undertaking a 
diversification strategy is to gain greater market power than its competitors (Sulastri, 2013).

Diversification of financing aims to reduce the probability of financing risk (default) financing customers in various sectors (Jahn et al., 2013). Financing risk reduction can be done by specializing in providing financing. This specialization can be achieved by reducing the ratio of financing diversification based on the type of financing ((Alshomaly, 2014);(Diamond, 1984)). For example, banks can diversify financing in the economic sector. Banks can also diversify financing based on the type of use, which includes the working capital sector, consumer sector, and investment sector).

Traditional banking theory shows that banks that diversify their financing portfolios can reduce the risk of financing. Less diversified banks will get the risk is higher for the economic downturn because they expose themselves to several sectors (Diamond, 1984). Diversification of financing has the benefit of one diversified bank that can be better able to absorb shocks. The shocks in question are that if there are unstable economic conditions, banks will be stronger protected from the risk of increasing bad credit and smaller bankruptcy risks faced (Guerry \& Wallmeier, 2017).

The implementation of diversification by banks requires monitoring costs in addition to profits. Banks will choose to diversify policy if the benefits of this policy outweigh the costs incurred ((Moudud-Ul-Huq et al., 2018); (Belguith \& Bellouma, 2018)). Although the cost of monitoring will reduce bank profitability, at the same time, financing diversification accompanied by supervision and monitoring will help offset credit risk to be lower. The selection of the right financing customers will save money in monitoring financing costs. This can maximize banking profitability (Prastiwi \& Anik, 2020).

Financing Diversification versus concentration of financing has become one of the most important issues to be discussed regarding bank stability ((Belguith \& Bellouma, 2018). Referring to the financing diversification theory, namely the classical financial theory shows that diversification must be a way to reduce credit risk ((Diamond, 1984). Whereas in reality, banks in the distribution of financing have two strategies that are diversification or concentration. Some banks decided to concentrate on the distribution of financing into sectors that they consider to have advantages.
This research aims to determine the impact of the diversification strategy based on the economic sector and the type of use which are the priority sectors of the government through banking on banking profitability. It is expected that policies, to encourage financing, can be developed, so that the banking contribution to economic growth can be increased (Otoritas Jasa Keuangan, 2015).

The classification of financing based on the economic sector is based on the need to determine the policy direction of bank financing qualitatively and emphasizes the economic sector that is prioritized in financing with bank financing (Christianti, 2011). In this study, the classification of financing by economic sector is classified into sectors: (a) Agriculture, Forestry and Agricultural Facilities, (b) Mining, (c) Industry, (d) Electricity, Gas and Water, (e) Construction, (f) Trade, restaurants, and hotels, (g) Transportation, Warehousing and Communication, (h) Social / Community Services. Diversification of financing by type of use is classified (Christianti, 2011): working capital, Investment, and Consumption.

\section{Review of Literature}

Profitability is the basis of the link between operational efficiency and the quality of services produced by banks. The more efficient the operations of a bank, the quality of services will increase. This can increase profitability. In Banking, the profitability ratio is used to measure the effectiveness of the overall management directed by the size of the level of profitability obtained about the distribution of financing and investment. By distribution of financing and investment maximum, Islamic banking gets maximum profitability.

Distribution of Islamic banking financing to maximalize profitability needs to be evaluated, among the banking strategies is to diversify financing to reduce the risk of bad financing and increase bank profitability. Most companies including banks use diversification strategies to enhance strategic competitiveness. When a diversification strategy increases strategic competitiveness, the company's performance will increase by competitors (Sulastri, 2013). Financing Diversification versus concentration of financing has become one of the most important issues to be discussed regarding bank stability ((Belguith \& Bellouma, 2018).

Referring to the financing diversification theory, namely the classical financial theory shows that 
diversification must be a way to reduce credit risk ((Diamond, 1984). Whereas in reality, the bank's distribution of financing has two strategies of diversification or concentration. Some banks decided to concentrate on the distribution of financing into sectors that they consider to have advantages.

Previous research also showed that diversification strategies affect financial performance, including Christianti (2011); Prastiwi\&Anik (2020)the results of the study indicate that diversification based on economic sectors influences on increasing bank profitability. (Nisar et al., 2018) diversification based on the economic sector's influence on increasing bank profitability. Molyneux \& Yip, (2013) survey on Islamic countries that practice multiple banking systems, found that diversification has a positive impact on banking performance found more in Islamic banking than conventional banking. Chatti et al.,(2013) examined eight Islamic banks in Malaysia and found that, despite low banking efficiency, portfolio diversification could improve the performance of these banks. Moudud-Ul-Huq et al., (2018), diversification can be beneficial if the activity diversified banks less risky, and have high returns. While diversification can be detrimental to the banking system if the diversified activities have high risks and low returns. Chen et al., (2018), the result shows that diversification affects the performance of banks in countries with multiple banking systems. However, diversification is appropriate for banks with large assets, both conventional banking and Islamic banking. Beck \& De Jonghe (2014) provide evidence from cross-country analysis and show that the concentration of financing in a few sectors can increase volatility and systemic risk exposure and not provide a higher return.Chepkorir et al., (2019) the diversification of activities of credit has reduced the credit risk in customer financing.

But there is also a diversification strategy that is not the right thing to reduce bank profitability. Mulwa (2018), the results showed that credit diversification based on the economic sector had a negative significant effect on the increasing profitability of banks in East Africa. Inder Singh, (2014), the result of this study that diversification does not help banks in Punjab increase profits, but on the contrary, it hurts profits. Acharya et al., (2006) the result of this study diversification reduces banking returns in Italy and increases the risk of bad credit.
Based on the description above, this research hypothesis is prepared whether the diversification of financing of Islamic banking has a positive impact on profitability or otherwise. Referring to the theory of financing diversification, whether diversification can increase profitability or reduce the profitability of Islamic banks, then it becomes interesting to do further research. Given the issue of diversification of Islamic banks, financing is growing widely still not tested. Thus, it is considered necessary to examine more deeply the effect of diversification of financing on the profitability of Islamic banks. This research hypothesis is:

H1: whether the financing diversification based on the economic sector of Islamic banking has a positive impact on profitability

$\mathrm{H} 2$ : whether the financing diversification based on the type of use of Islamic banking has a positive impact on profitability

\section{RESEARCH METHOD}

This type of research is a quantitative study using secondary data. Variables in this research are financing diversification based on the economic sector (X1), financing diversification based on types of use (X2), and profitability (Y). Profitability is the ratio used to measure the effectiveness of overall company management as indicated by the number of profits earned by the company, in this case, is an Islamic reproduction. In this study, the ratio used to measure the performance of a company is Return on Assets (ROA). According to Moudud-Ul-Huq et al (2018), the best proxy for measuring bank performance is the ROA ratio.

The higher ROA produced by a company, the better the company in improving the company's financial performance. Based on the Financial Services Authority Circular Letter Number 10 / SEOJK.03 / 2014 Regarding the Health Level Assessment of Islamic Commercial Banks and Islamic Business Units, the ways to measure ROA are as follows:

$$
R O A=\frac{\text { Net profit }}{\text { Total assets }} \times 100 \%
$$

Diversification of financing based on economic sectors is classified into 8 sectors, namely (1) Agriculture, Forestry, and Agricultural Facilities; (2) Mining; (3) Industry; (4) Electricity, Gas and Water; (5) Construction; (6) Trade, restaurants, and hotels; (7) Transportation, Warehousing and 
Communication; (8) Social / Community Services. While financing diversification based on the type of use is classified into 3 categories: (1) working capital; (2) investment; (3) consumption.

The population of this study is Islamic Banking in Indonesia. while the sample data is Islamic Commercial Banks and Islamic Business Units in Indonesia for the period of January 2014 - December 2018. The data consists of Islamic banking monthly financial reports published in sharia banking statistics reports, the total sample data in this study were 60 data. The main sources of data are (1) financing table reports based on the business field and not the business field receiving the financing, (2) financing, and NPF based types of use and business categories of Indonesian Islamic Banking Statistics.

This research uses the method of multiple linear regression analysis. Before proceeding to multiple linear regression analysis, the data are tested on classical assumptions first so they are not biased.

The method for measuring diversification variables and financing risks is to use the Hirschman Herfindahl Index (HHI). The Herfindahl Index is defined as the result of industrial sales divided by sales of each industry segment ((Meija, 2011); (Acharya et al., 2006)). HHI shows how concentrated a company is in its business segment (Siregar, Sylvia Veronica Diyanty, Vera Christiningrum, MF Yuniasih, 2014). The index has a value of 0 to 1 . According to The Federal Trade and Commission in the US, companies are said to be diversified if the value of $\mathrm{HHI}$ is smaller than 0.18 . HHI index value is 0 , then the market is in the low concentrated category, and vice versa. The higher the value of HHI, the higher the distributed company ((Chandini Dewi et al., 2017); (Buch et al., 2006)). The following formula for calculating HHI ((Meija, 2011); (Acharya et al., 2006); (Buch et al., 2006)):

$$
H H I=\sum_{i=1}^{n}\left(\frac{X_{i}}{Q}\right)^{2}
$$

HHI = Hirschman Herfindahl Index

and $\quad=$ the number of groups measured $\begin{array}{ll}\mathrm{i} & =\text { the group measured } \\ \mathrm{Xi} & =\text { total group financing } \\ \mathrm{Q} & =\text { total financing provided by the bank }\end{array}$

\section{RESULT AND DISCUSSION}

\subsection{Results}

\section{Data and Sample Selection}

The data in this study are the data of Islamic Commercial Banks and Islamic Business Units in Indonesia for the period of January 2014 - December 2018. The main sources of data are (1) financing table reports based on the business field and not the business field receiving the financing, (2) financing, and NPF based types of use and business categories of Indonesian Islamic Banking Statistics.

Before proceeding to multiple linear regression analysis, the data are tested on classical assumptions first so they are not biased. Normality test results are:

Table 1. One-Sample Kolmogorov-Smirnov Test

\section{One-Sample Kolmogorov-Smirnov Test}

\begin{tabular}{ll|r}
\hline & & $\begin{array}{c}\text { Unstandardized } \\
\text { Residual }\end{array}$ \\
\hline $\mathrm{N}$ & & 60 \\
Normal Parameters & Mean & .0000000 \\
& Std. & .00283812 \\
Most Extreme & Deviation & .080 \\
Differences & Absolute & .048 \\
& Positive & -.080 \\
Test Statistic & Negative & .080 \\
Asymp. Sig. (2-tailed) & & $.200^{\mathrm{c}, \mathrm{d}}$ \\
\hline
\end{tabular}

a. Test distribution is Normal.

b. Calculated from data.

c. Lilliefors Significance Correction.

$\mathrm{d}$. This is a lower bound of the true significance.

Data source: Data processed by SPSS 2019

A good regression model is to meet the assumption of normality. Based on table 1 above, the data are normally distributed because the asymp.sig.(2-tailed) shows that $0.200>0.05$, so it can be concluded that the data is normally distributed or passed the normality test.

The multicollinearity test results are as follows:

Table 2The Test of Multicollinearity

Coefficients $^{\mathrm{a}}$

\begin{tabular}{|l|c|c|c|c|c|c|c||}
\hline \multirow{3}{*}{ Model } & \multicolumn{2}{|c|}{ Unstandardized Coefficients } & Standardized Coefficients & $\mathrm{t}$ & \multicolumn{2}{|c|}{ Sig. } & \multicolumn{2}{|c|}{ Collinearity Statistics } \\
\cline { 2 - 7 } & $\mathrm{B}$ & Std. Error & Beta & & & Tolerance & VIF \\
\hline 1 (Constant) & -.022 & .060 & & -.358 & .722 & & \\
LOG_HHIE & .073 & .036 & .310 & 2.023 & .048 & .442 & 2.260 \\
LOG_HHIJ & -.199 & .082 & -.373 & -2.433 & .018 & .442 & 2.260 \\
\hline
\end{tabular}

a. Dependent Variable: ROA 
Data source: Data processed by SPSS 2019

If the VIF value is less than 10 and or the Tolerance value is more than 0.01 then it can be interpreted that there is no multicollinearity problem, and vice versa. Based on table 2 above, the values of the two independent variables show a tolerance value of $0.442>0.1$ or a VIF value of $2.260<10$, then conclude that between independent variables there is no multicollinearity or passing the Multicollinearity Test.

Autocorrelation Test Results are as follows:

Table 3. Durbin Watson Test

Model Summaryb

\begin{tabular}{l|r|r|r|r|r|r|r|r|r|r}
\hline \multirow{2}{*}{ Model } & $\mathrm{R}$ & $\mathrm{R}$ & \multirow{2}{*}{$\begin{array}{c}\text { Adjusted R } \\
\text { Square }\end{array}$} & $\begin{array}{c}\text { Std. Error of } \\
\text { Square }\end{array}$ & \multicolumn{4}{|c|}{ Change Statistics } & Durbin-Watson \\
\cline { 6 - 10 } & & & $\begin{array}{l}\text { R Square } \\
\text { the Estimate }\end{array}$ & F Change & df1 & df2 & $\begin{array}{c}\text { Sig. F } \\
\text { Change }\end{array}$ & \\
\hline 1 & $.639 \mathrm{a}$ & .408 & .387 & .002887484 & .408 & 19.620 & 2 & 57 & .000 & .834 \\
\hline
\end{tabular}

a. Predictors: (Constant), LOG_HHIJ, LOG_HHIE

b. Dependent Variable: ROA

Data source: Data processed by SPSS 2019

The results of the autocorrelation test carried out by the Durbin Watson test with a result of 0.727 where -2 $<0.834<2$, it can be concluded that this study is also free of autocorrelation symptoms.

Heteroskedasticity Test with Glejser test is as follows:

Table 4. Glejser Test

Coefficients $^{\mathbf{a}}$

\begin{tabular}{|c|c|c|c|c|c|c|c|}
\hline \multirow{2}{*}{ Model } & \multicolumn{2}{|c|}{ Unstandardized Coefficients } & \multirow{2}{*}{\begin{tabular}{|c|} 
Standardized Coefficients \\
Beta \\
\end{tabular}} & \multirow[t]{2}{*}{$\mathrm{t}$} & \multirow[t]{2}{*}{ Sig. } & \multicolumn{2}{|c|}{ Collinearity Statistics } \\
\hline & $\mathrm{B}$ & Std. Error & & & & Tolerance & VIF \\
\hline (Constant) & -.065 & .039 & & -1.690 & .096 & & \\
\hline 1 LOG_HHIE & -.043 & .023 & -.364 & -1.884 & 065 & 442 & 2.260 \\
\hline LOG_HHIJ & -.076 & .052 & -.280 & -1.448 & .153 & .442 & 2.260 \\
\hline
\end{tabular}

a. Dependent Variable: ABS_RES_1

Based on table 4, the sign value.for LOG_HHIE and LOG HHIJ are 0.065 and 0.153 , both bigger than alpha 0.05 , or the 0.065 and $0.153>0.05$ for the independent variable. It means that heteroscedasticity does not occur or passes the heteroscedasticity test.

\section{Determination Coefficient $\left(R^{2}\right)$ Test Results}

Table 5. Coefficient of Determination (R2)

Model Summary ${ }^{b}$

\begin{tabular}{|c|c|c|c|c|c|c|c|c|c|c|}
\hline \multirow[b]{2}{*}{ Model } & \multirow[b]{2}{*}{$\mathrm{R}$} & \multirow[b]{2}{*}{$\begin{array}{c}\mathrm{R} \\
\text { Square }\end{array}$} & \multirow[b]{2}{*}{$\begin{array}{c}\text { Adjusted R } \\
\text { Square }\end{array}$} & \multirow[b]{2}{*}{$\begin{array}{l}\text { Std. Error of } \\
\text { the Estimate }\end{array}$} & \multicolumn{5}{|c|}{ Change Statistics } & -Watson \\
\hline & & & & & $\begin{array}{l}\text { R Square } \\
\text { Change }\end{array}$ & F Change & df1 & df2 & $\begin{array}{l}\text { Sig. F } \\
\text { Change }\end{array}$ & \\
\hline 1 & $.639^{\mathrm{a}}$ & .408 & .387 & .002887484 & .408 & 19.620 & 2 & 57 & .000 & .834 \\
\hline
\end{tabular}

a. Predictors: (Constant), LOG_HHIJ, LOG_HHIE

b. Dependent Variable: ROA

Source: Data processed 2019

The results show that the magnitude of the influence of the contribution of the independent variable that is financing diversification based on the economic sector and the type of use to the profitability of Islamic banking indicated by Adjusted R Square of $38,7 \%$ and the remaining $61.3 \%$ is influenced by other variables outside the model submitted in this study.

Results of F Test Statistics
F Statistical Test Results are as follows:

Table 6. F Statistical Test Results

ANOVA ${ }^{a}$

\begin{tabular}{|l|c|r|r|l|l|}
\hline Model & $\begin{array}{c}\text { Sum of } \\
\text { Squares }\end{array}$ & Df & $\begin{array}{c}\text { Mean } \\
\text { Square }\end{array}$ & F & Sig. \\
\hline 1 Regression & .000 & 2 & .000 & 19.620 & $.000^{\mathrm{b}}$ \\
Residual & .000 & 57 & .000 & & \\
Total & .001 & 59 & & & \\
\hline
\end{tabular}

a. Dependent Variable: ROA 
b. Predictors: (Constant), LOG_HHIJ, LOG_HHIE

Source: Data processed 2019

The results of the $\mathrm{F}$ test show an $\mathrm{F}$ count of 19.260 with a sig value of 0.000 which means that there is a significant and simultaneous influence of financing diversification based on the economic sector and the type of use to the profitability of Islamic banking in Indonesia. This $\mathrm{F}$ test also shows that regression models are linear. It means that this regression model has accurately described the factors that influence the performance of Islamic banks in Indonesia, namely diversifying.

\section{Hypothesis Test Results}

The results of this study indicate that the variable of financing diversification based on the type of use has a significant influence on the profitability of Islamic banking in a negative direction. While the variable diversification of financing based on economic sectors affects the profitability of Islamic banking in a positive direction. So from the tests that have been carried out it can be seen the regression equation produced in this study are as follows:

$$
\begin{aligned}
& \text { ROA }=-0.022+0.073 \text { LOG_HHIE }-0.199 \\
& \text { LOG_HHIJ }+ \text { er }
\end{aligned}
$$

From the estimated regression model it is known that the impact arising from the influence provided by the HHI of diversification of financing based on the economic sector is 0.073 with a positive direction on the profitability of Islamic banking. While HHI of financing diversification based on the type of use produces a value of 0.199 with a negative direction towards the profitability of Islamic banking in Indonesia.

\subsection{Discussion}

Based on the results of the hypothesis test above, the magnitude of the influence HHI of diversification of financing based on the economic sector has significant influence with a positive direction on the Islamic bank's profitability. This means that the more banks diversify financing into the economic sector, the lower the concentration of Islamic banks in the distribution of financing, the closer it is to the 0 HHIE concentration index, the lower the profitability of Islamic banks. This research is in line with the research from (Tabak et al., (2011); Inder Singh (2014)) which states that credit diversification based on high economic sectors, reduces the profitability of Islamic banks. But it is different from the results of research Mulwa (2018); and Christianti (2011) which states that the more banks diversify credit to various sectors, the more bank profitability increases.

The results of this study can be explained by the results of the HHI index of financing diversification based on the economic sector, as the following graph:

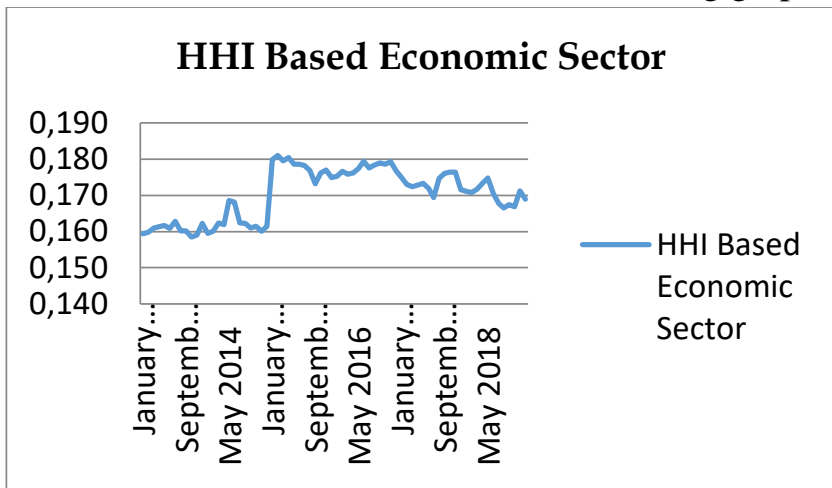

Graph 3. Value of HHI Diversification of Financing

Based on Economic Sector Islamic Bank

Data source: Islamic Banking Statistics (processed, 2019)

Based on Graph 3 above, shows the average value of HHI diversification of financing based on economic sectors is 0.170 . This value is less than 0,18 , meaning that diversification tends to be high, which means Islamic banks distribute financing to various economic sectors, not just focus on a few sectors. However, this can impact on the profitability of Islamic banks. Islamic banking must examine policies to diversify financing into various economic sectors because it can hurt profitability.

Some opinions do recommend that banks diversify to maximize performance. However, these results indicate that diversification of financing reduces bank profitability. This appears to be due to several reasons, including First, poor financing monitoring. Banks may not have expertise in monitoring new economic sectors. Also, the monitoring process in implementing banking diversification policies can reduce cost-efficiency. Likely, the number of monitoring costs can directly affect the achievement of bank profitability (ROA). Second, the risk of financing Indonesian banks may be higher. Many things that affect the characteristics of the community in returning credit loans differ between countries, it could be because of people's morals, the level of economic prosperity, and so on. Third, it lacks good experience in diversification. Fourth, it could also be due to intense banking competition. Banking competition in the target of distribution of large 
amounts of financing has caused banks to be unfavorable in the selection of distribution of financing.

Based on the results of this study, Indonesian Islamic banking needs to focus more on the distribution of financing to only a few potential sectors, as shown in the following table of the distribution of Islamic banking financing in Indonesia:

Table 7. Distribution of Islamic Banking Financing in Indonesia As of December (In Billion IDR)

\begin{tabular}{|l|r|r|r|r|r|}
\hline Distribution of Financing to the Economic Sector & \multicolumn{1}{|c|}{2014} & \multicolumn{1}{c|}{2015} & \multicolumn{1}{c|}{2016} & \multicolumn{1}{c|}{2017} & \multicolumn{1}{c|}{2018} \\
\hline Agriculture, Forestry, and Agricultural Facilities & 5.679 & 7.950 & 8.531 & 10.419 & 11.497 \\
\hline Mining & 4.597 & 6.145 & 6.604 & 6.864 & 5.410 \\
\hline Industry & 13.300 & 17.982 & 19.745 & 21.463 & 24.363 \\
\hline Electricity, Gas, and Water & 5.492 & 6.427 & 8.117 & 11.044 & 16.600 \\
\hline Construction & 11.669 & 11.193 & 14.435 & 22.198 & 24.648 \\
\hline Trade, restaurants, and hotels & 24.287 & 25.993 & 30.319 & 32.839 & 33.166 \\
\hline Transportation, Warehousing, and Communication & 12.192 & 11.072 & 10.921 & 10.087 & 9.374 \\
\hline Social / Community Services & 11.022 & 2.550 & 3.030 & 4.021 & 4.788 \\
\hline
\end{tabular}

Source: Indonesian Islamic Banking Statistics, data processed (2019)

As based on the above table, Islamic banking is quite focused on several sectors that are felt to be beneficial, such as the trade, restaurant and hotel sectors, the industrial sector, the construction sector, and the Transportation, Warehousing, and Communication sectors.

Islamic banking provides less funding for the mining sector because the mining sector in general is long-term financing, so it requires higher funds. While the distribution of funding for the agriculture sector, forestry, and agricultural facilities, Islamic banking is also less than the other sectors. This is because the target of financing customers is dominated by small and medium-sized communities with small and medium scale financing. In Indonesia, small and medium scale financing is not only provided by Islamic banking but "koperasi" and Baitul Maat Wat Tamwil (BMT) also provide funding to them. Koperasi and BMT in Indonesia is an institution that also provides sharia financing services to the public. This makes Islamic banking in channeling credit in the agriculture, forestry, and agricultural facilities sectors not too large.

Distribution of Islamic banking loans to sectors with high risk, causing high non-performing loans to need to be reduced. Sectors that have the potential to cause high non-performing loans need to be reduced. $\mathrm{Bad}$ credit is considered as one of the main problems in terms of financial health and bank health (Mostak Ahamed, 2017). High non-performing loans have a significant impact on the entire economy of a country. High credit risk can affect the profitability of Islamic banking.
This policy of reducing the distribution of funding to sectors that are considered high risk (bad credit) creates a dilemma between banks and the government. Banking is oriented towards maximum profitability, while the government is oriented to providing working capital by involving banks as providers of funds to the public. For the government, banking is a significant supporting factor for the growth of the real sector. Banking becomes the driving force of the national economy by creating jobs. This can be done if banks distribute financing to the public in various productive sectors, such as industry, agriculture, fisheries which absorb a lot of jobs. The orientation of interests between banks and the government must continue to be carried out with each maximum, but it must still be adopted policies that benefit all parties, both banks, and the government.

This study provides results that can be an evaluation of Islamic banking in Indonesia is concentrated in the finance portfolio. If Islamic banks provide financing that is concentrated in several economic sectors, this can reduce the cost of monitoring financing customers affects increasing profitability of Islamic banking. According to Simpasa \& Pla (2016), the cost of monitoring minimum financing can maximize efficiency and increasing the profitability of banking. This policy has the effect of imposing potential risks on the concentration sector.

While the diversification of financing by type of use shows a significant negative effect on Islamic bank's profitability. The effect of diversification of 
financing by type of use has a negative direction on Islamic bank's profitability, this means that the higher the diversification of Islamic bank financing by type of use, the lower the concentration, the closer it is to 0 HHI index, the higher the impact profitability.

Diversification of financing based on the type of use has a negative influence on the profitability of Islamic banks can be explained based on the HHI indicator (Hirschman Herfindahl Index), where if the value of $\mathrm{HHI}$ approaches 0 then financing diversification tends to be high, meaning that Islamic bank financing is more focused on one or several sectors and vice versa. Diversification of financing based on the type of use shows the value of HHI as shown in the following figure:

\section{HHI Based on Usage Type}

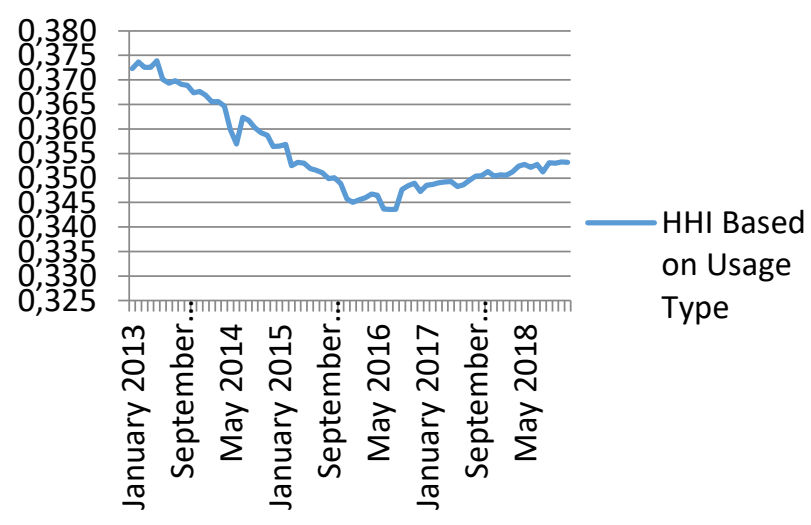

Graph 4. Value of HHI Diversification of Financing

Based on Usage Type Islamic Bank

Data source: Islamic Banking Statistics (processed, 2019)

From graph 4 above, it can be seen that the distribution of Islamic bank financing based on the type of use shows an average HHI value of 0.355 greater than 0.18 . This means that the diversification of financing by type of use tends to be lower. Diversification of financing based on the type of use has a negative influence on the profitability of Islamic banks means shows that the distribution of Islamic bank financing is more focused on the consumption sector, compared to working capital and investment have an impact on the decline in profitability of Islamic Banks. The results of the study that the largest Islamic bank financing to the consumption sector is not new news. Islamic banking is boosting consumer financing in 2017 to improve its performance. Until mid-2018 several Islamic banks were able to score quite a high financing growth in the consumption sector. Financing in the consumption sector is easier, making banking more popular.

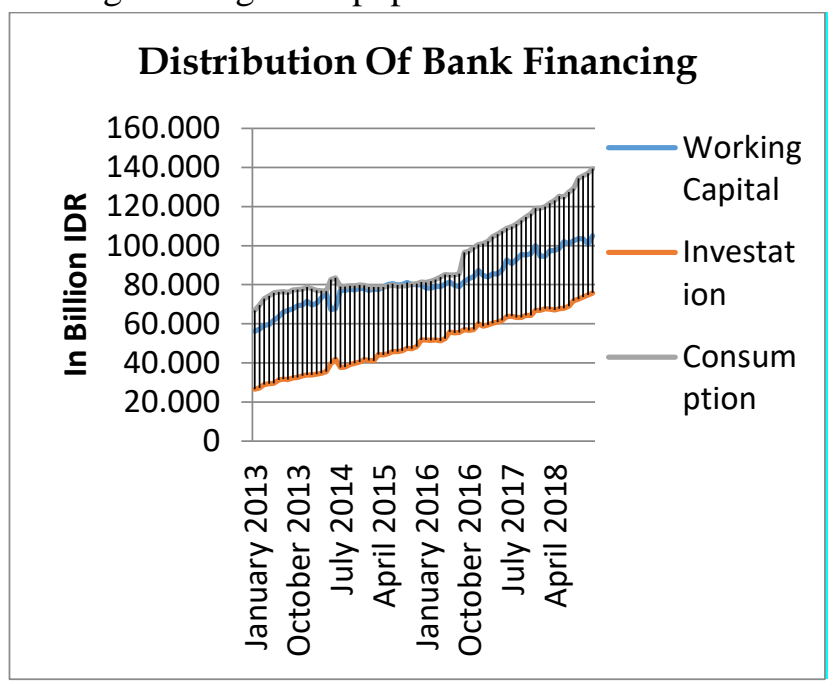

Graph 5. Funding Distribution Chart Islamic Bank Data source: Islamic Banking Statistics (processed, 2019)

Based on Graph 5 above, the distribution of financing in the consumption sector is still dominant for banks, including Islamic banks. The results of this study indicate that if Islamic banking only focuses on channeling financing to the consumption sector, it can have an impact on decreasing profitability. So that Islamic banking needs to equalize the distribution of consumption to the working capital and investment sectors. Currently, banks are still dominated by financing in the consumption sector rather than productive. This is due to the easier process of proposing financing in the consumption sector. In general, productive sector financing (investment and working capital) requires a business feasibility analysis as a basis for banking to assess whether or not the business actor receives financing from the banking sector. Also, the productive sector, both the investment sector and working capital, depends on the mindset of the community and the conditions of the local community.

Based on the study's result, the distribution of Islamic banking financing distribution needs to be equated with other sectors, namely the working capital and investment sectors. Bank Indonesia has formulated a policy to encourage lending to the productive sector, regarding the rising trend in consumer financing. The distribution of Islamic banking financing to the working capital and investment sectors also helps the government program to provide working capital for Small and Medium 
Enterprises (MSMEs). So far, Islamic banking is quite concentrated in the distribution of consumption sector financing alone.

But it should be recognized that the consumption sector is indeed the driving force of economic growth. But if overconsumption financing can encourage inflation and vice versa if economic growth is driven by the productive sector (investment and working capital) then it can reduce the inflation rate.

This study is to examine diversification's effect of financing by the economic sector on the profitability of Islamic banking. The results of this study show that diversified financing can have an impact on the decline in the profitability of Islamic banks. This has implications for the future that Islamic banking must examine policies to diversify financing into various economic sectors. Islamic banking will do diversification strategy or to be more focused in the distribution of fund distribution to only a few potential sectors. This study also aims to determine diversification's effect of financing by type of use on profitability. The Result is if Islamic banking only focuses on channeling financing to the consumption sector, it can have an impact on decreasing profitability. This has implications for the future that Islamic banking needs to equalize the distribution of consumption to the working capital and investment sectors.

This research effort has been made and implemented following the scientific procedure, however, still has limited the research done using only secondary data and only use financial ratios as a representation of several financial ratios that exist which also has drawbacks in terms of accuracy. Also, there are other variables as control variables that affect the dependent variable that has not been included in this study, such as banking size, banking liquidity, and so on.

\section{CONCLUSION}

This study is to examine diversification's effect of financing by the economic sector on the profitability of Islamic banking. The results in this study are the diversified financing by the economic sector is high, the impact of reducing the profitability of Islamic banks in Indonesia. Indonesian Islamic banking distribution of finance to various economic sectors, not only focusing on a few sectors. Islamic banking needs to be more focused on the distribution of fund distribution to only a few potential sectors. Such as the trade, restaurant and hotel sector, and the industrial sector. Sectors that have the potential to cause high non-performing loans need to be reduced. Banks that provide financing that is concentrated in several economic sectors, can reduce the cost of monitoring financing customers. This policy has the effect of imposing potential risks on the concentration sector. The results of this study show that diversified financing can have an impact on the decline in the profitability of Islamic banks. So that Islamic banking must examine policies to diversify financing into various economic sectors.

This study also aims to determine diversification's effect of financing by type of use on profitability. The results in this study can indicate that diversification of financing based on the type of use that is low tends to reduce the profitability of Islamic banks. This means that if Islamic banking only focuses on channeling financing to the consumption sector, it can have an impact on decreasing profitability. So that Islamic banking needs to equalize the distribution of consumption to the working capital and investment sectors. Currently, banks are still dominated by financing in the consumption sector rather than productive, namely the investment sector and working capital. Bank Indonesia has formulated a policy to encourage lending to the investment and working capital sectors. The distribution of Islamic banking financing to the working capital and investment sectors also helps the government program to provide working capital for Small and Medium Enterprises (MSMEs). So far, Islamic banking is quite concentrated in the distribution of consumption sector financing alone. If the distribution of financing in the excess consumption sector can encourage inflation and vice versa if economic growth is driven by the productive sector (investment and working capital) then it can reduce the inflation rate.

Further research is expected to use the primary data source, additional qualitative data by the method of literature study and interviews with informants. Also, researchers can then add a control variable in it.

\section{ACKNOWLEDGMENTS}

The author would like to thank the whole extended family of ITB AAS Indonesia for their support in completing this research. Thank you also to ITB AAS Indonesia Sharia Economics study program students and all those who helped a lot in this research. 
profitabilitas dan probabilitas kegagalan bank. Jurnal Keuangan Dan Perbankan, 15(3), 428436.

\section{REFERENCES}

Acharya, V. V., Hasan, I., \& Saunders, A. (2006). Should banks be diversified? Evidence from individual bank loan portfolios. Journal of Business, 79(3), 1355-1412. https://doi.org/10.1086/500679

Alshomaly, I. (2014). Bank Diversification \& the Systematic Risk of Equity Portfolio. Europan Scientific Journal, 10(16), 171-184.

Beck, T., \& De Jonghe, O. (2014). Lending Concentration, Bank Performance and Systemic Risk. In World Development Report 2014: Background Paper (Issue September 2013).

Belguith, H., \& Bellouma, M. (2018). The Impact of Loan Portfolio Diversification on Tunisian Bank's Profitability. International Journal of Emerging Research in Management and Technology, 6(6), 35. https://doi.org/10.23956/ijermt.v6i6.242

Buch, C. M., Schertler, A., \& Westernhagen, N. Von. (2006). Heterogeneity in lending and sectoral growth : evidence from German bank-level data. Discussion Paper Series 2: Banking and Financial Studies. Banking, 04.

Chandini Dewi, G. A. K., Wiagustini, L. P., \& Panji, S. I. . (2017). Peran Profitabilitas Memediasi Pengaruh Diversifikasi Terhadap Return Saham. Jurnal Ekonomi Dan Bisnis Universitas Udayana, 6(1), 167-196.

Chatti, M. A., Kablan, S., \& Yousfi, O. (2013). Are Islamic Banks Sufficiently Diversified?: An Empirical Analysis of Eight Islamic Banks in Malaysia. Islamic Economic Studies, 21(2), 2354. https://doi.org/10.12816/0001557

Chen, N., Liang, H. Y., \& Yu, M. T. (2018). Asset diversification and bank performance: Evidence from three Asian countries with a dual banking system. Pacific Basin Finance Journal, 52(August 2017), 40-53. https://doi.org/10.1016/j.pacfin.2018.02.007

Chepkorir, D., Nyamweya, S., \& Mureithi, G. (2019). Effect of Bank Diversification on the Financial Distress of Commercial Banks Listed at the Nairobi Securities Exchange, Kenya. IOSR Journal of Business and Management (IOSRJBM), 21(6), 39-45. https://doi.org/10.9790/487X-2106043945

Christianti, A. (2011). Diversifikasi kredit terhadap
Daud, W. M. N. W., Norwani, N. M., Mansor, A. A., \& Endut, W. A. (2016). Does financing decision influence corporate performance in Malaysia? International Journal of Economics and Financial Issues, 6(3), 1165-1171.

David, F. R. (2008). Manajemen Strategis: Konsep. (10th ed.). Salemba Empat.

Diamond, D. (1984). Financial intermediation and delegated monitoring.The Review of Economic Studies, 51(3), 393414.https://doi.org/10.2307/2297430

Guerry, N., \& Wallmeier, M. (2017). Valuation of diversified banks: New evidence. Journal of Banking and Finance, 80, 203-214. https://doi.org/10.1016/j.jbankfin.2017.04.004

Inder Singh, R. (2014). Central Cooperative Banks in Punjab. Journal of Finance and Bank Management, 2(2), 27-41.

Jahn, N., Memmel, C., \& Pfingsten, A. (2013). Banks' concentration versus diversification in the loan portfolio: New evidence from Germany. In Bundesbank Discussion Paper (Issue 53).

Kuncoro, M. dan S. (2002). Manajemen Perbankan Teori dan Aplikasi. BPFE.

Marwa, C. N. (2013). Performance Appraisal Practices Among Commercial Banks in Kenya. October. Unpublished master's thesis. Business Administration:University Of Nairobi

Meija, J. F. (2011). Export Diversification and Economic Growth: An Analysis of Columbia's Export Competitiveness in the European Union's Market. Springer Science \& Business Media. https://doi.org/10.1007/978-3-79082742-2

Molyneux, P., \& Yip, J. (2013). Income diversification and performance of Islamic banks. Journal of Financial Management, Markets and Institutions, 1, 47-66. https://doi.org/10.12831/73632

Mostak Ahamed, M. (2017). Asset quality, noninterest income, and bank profitability: Evidence from Indian banks. Economic Modelling, 63(January), 1-14. https://doi.org/10.1016/j.econmod.2017.01.016

Moudud-Ul-Huq, S., Ashraf, B. N., Gupta, A. Das, \& Zheng, C. (2018). Does bank diversification heterogeneously affect performance and risktaking in ASEAN emerging economies? 
Jurnal Akuntansi dan Pajak, 21 (02), 2021, 423

Research in International Business and Finance, 46 , $342-362$. https://doi.org/10.1016/j.ribaf.2018.04.007

Mulwa, J. M. (2018). Sectoral credit diversification , bank performance and monitoring effectiveness ; a cross-country analysis of east African banking industries. Journal of Finance and Invesment Analysis, 7(2), 17-36.

Munawir, S. (2002). Analisa Laporan Keuangan. Liberty.

Nisar, S., Peng, K., Wang, S., \& Ashraf, B. N. (2018). The Impact of Revenue Diversification on Bank Profitability and Stability: Empirical Evidence from South Asian Countries. International Journal of Financial Studies, 6(2), 40. https://doi.org/10.3390/ijfs6020040

Otoritas Jasa Keuangan. (2015). Potensi Pertumbuhan Ekonomi ditinjau dari Penyaluran Kredit Perbankan Kepada Sektor Prioritas. Otoritas Jasa Keuangan Indonesia, 58.

Prastiwi, I. E., \& Anik. (2020). Diversifikasi Kredit, Monitoring dan Kinerja Perbankan di Indonesia. Jurnal Ilmiah Ekonomi Islam,6(01), 80-86. https://doi.org/ttp://dx.doi.org/10.29040/jiei.v6i 1.775

Prastiwi, I. E., \& Anik. (2020). The Impact of Credit Diversification on Credit Risk and Performance of Indonesian Banks. Global Review of Islamic Economics and Bisiness, 8(01), 13-21. https://doi.org/10.14421/grieb.2020.081-02

Siamat, D. (2005). Manajemen Lembaga Keuangan. "Kebijakan Moneter dan Perbankan" (1st ed.). Faculty of Economics, University of Indonesia.

Simpasa, A., \& Pla, L. (2016). Sectoral Credit Concentration and Bank Performance in
Zambia. The Working Paper Series (WPS), 245(245), 25.

Siregar, Sylvia Veronica Diyanty, Vera Christiningrum, MF Yuniasih, R. (2014). Efek Entrenchment dan Alignment Pemegang Saham Pengendali pada Strategi Diversifikasi dan Kinerja Perusahaan dan Peran Corporate Governance. 24-27. https://www.academia.edu/21040387/Efek_Entr enchment_Dan_Alignment_Pemegang_Saham_ Pengendali_Pada_Strategi_Diversifikasi_Dan_ Kinerja_Perusahaan_Dan_Peran_Corporate_Go vernance

Sulastri, U. (2013). Pengaruh Strategi Diversifikasi Terhadap Kinerja Keuangan Perusahaan Dengan Struktur Modal Sebagai Variabel Intervening (Pada Perusahaan Sektor Properti dan Real Estate di Bursa Efek Indonesia Periode 20092013. Unpublished master's thesis. Accounting Department, Faculty of Economics. The State University of Surabaya

Tabak, B. M., Fazio, D. M., \& Cajueiro, D. O. (2011). The effects of loan portfolio concentration on Brazilian banks' return and risk. Journal of Banking and Finance, 35(11), 3065-3076. https://doi.org/10.1016/j.jbankfin.2011.04.006

Turkmen, S. Y., \& Yigit, I. (2012). Diversification in Banking and its Effect on Banks' Performance: Evidence from Turkey. American International Journal of Contemporary Research, 2(12), 111119.

Umam, K. (2013). Manajemen Perbankan Syariah. Pustaka Setia.

Weygandt et.al. (2009). Accounting Principles. Salemba Empat. 